\title{
Isu Strategis Tata Kelola Pembangunan Berkelanjutan (Studi pada Kabupaten Sampang, Provinsi Jawa Timur)
}

\author{
Andy Fefta Wijaya, M. Chazienul Ulum ${ }^{a}$ * \\ ${ }^{a}$ Universitas Brawijaya, Malang, Jawa Timur, Indonesia
}

\section{INFORMASI ARTIKEL}

\section{Article history:}

Dikirim tanggal: 19 November 2019

Revisi pertama tanggal: 10 Desember 2019

Diterima tanggal: 14 Desember 2019

Tersedia online tanggal: 30 Desember 2019

Keywords: strategic issue, sustainable development, triple bottom line

\section{ABSTRACT}

Sustainable development seeks to equitably distribute development outcomes across various groups and layers of society and among generations. The prerequisite for achieving sustainable development is environmentally sound development. It means that development is compatible with the environment so that it does not interfere with its ecological function. That function is needed for the sustainability of development, even for human survival. Identifying strategic issues can help organizations, including in the public sector, pay attention to what is really important in long-term decision making. The purpose of this paper is to study the strategic issues of sustainable development in Sampang Regency, East Java Province.

\section{INTISARI}

Pembangunan berkelanjutan berupaya mendistribusikan hasil pembangunan secara merata ke berbagai kelompok dan lapisan masyarakat dan antar generasi. Prasyarat untuk mencapai pembangunan berkelanjutan adalah pembangunan berwawasan lingkungan. Hal ini berarti bahwa pembangunan kompatibel dengan lingkungan agar tidak mengganggu fungsi ekologisnya. Fungsi itu diperlukan untuk keberlanjutan pembangunan, bahkan untuk kelangsungan hidup manusia. Mengidentifikasi isu-isu strategis dapat membantu organisasi, termasuk di sektor publik, memperhatikan apa yang benar-benar penting dalam pengambilan keputusan jangka panjang. Tujuan dari paper ini adalah untuk mempelajari isu-isu strategis pembangunan berkelanjutan di Kabupaten Sampang, Provinsi Jawa Timur.

2019 FIA UB. All rights reserved.

\section{Pendahuluan}

Pada prinsipnya tujuan dari pembangunan adalah demi peningkatan kesejahteraan rakyat dan kualitas kehidupan manusia. Dalam konteks pembangunan berkelanjutan tentunya juga mengindahkan tiga pilar yang populer disebut sebagai triple bottom line, yaitu lingkungan, ekonomi, dan sosial. Model pembangunan tersebut telah direkomendasikan secara global dan kini juga menjadi mainstream, selain growth strategy yang telah sekian lama dikenal dan dipraktekkan.

Keberlanjutan adalah tentang kontinuitas. Setiap kali ada perasaan urgensi yang kuat mungkin juga ada keterlibatan isu keberlanjutan. Urgensi ini dapat bertautan dengan existing condition dan prediksi yang akan terjadi. Dalam konteks ekosistem, misalnya, keanekaragaman hayati mungkin terancam punah dimasa

\footnotetext{
* Corresponding author. Tel.: +62-853-3491-6305; e-mail: mochamad.ulum@gmail.com
} 
mendatang -dengan melihat kecenderungan yang ada (Ulum \& Ngindana, 2017).

Dalam pada itu, identifikasi isu strategis dapat membantu organisasi, termasuk di sektor publik, untuk memperhatikan apa yang sebenarnya penting dalam pengambilan keputusan jangka panjang. Domain identifikasi isu strategis bisa luas, tersebar dan tidak jelas. Karena isu strategis tidak ditentukan sebelumnya, proses mengidentifikasi makna untuk isu ini dan menemukan solusinya adalah dinamis. Dengan demikian, jenis isu strategis yang dihadapi, serta bagaimana berbagai isu ini didiagnosis dan dibentuk mempengaruhi isu mana yang termasuk dalam konteks pembangunan (berkelanjutan).

Diantara kabupaten/ kota yang ada, Sampang menjadi salah satu 'objek' atensi dari pemerintah, khususnya Pemerintah Provinsi Jawa Timur, untuk benar-benar serius merealisasikan tujuan pembangunan berkelanjutan. Karenanya, Sampang merupakan kabupaten yang berkomitmen dalam melaksanakan pembangunan berkelanjutan. Secara administratif, kabupaten ini berada dalam wilayah Provinsi Jawa Timur. Secara geografis terletak di antara $113^{\circ} 08^{\prime}-113^{\circ}$ 39' Bujur Timur dan $6^{\circ} 05^{\prime}-7^{\circ} 13^{\prime}$ Lintang Selatan. Kabupaten Sampang mempunyai luas wilayah 1.233,30 $\mathrm{km}^{2}$. Proporsi luasan 14 kecamatan terdiri dari enam kelurahan dan 180 desa. Kecamatan terluas adalah Kecamatan Banyuates dengan luas 141,03 km ${ }^{2}$ atau 11,44 $\%$, sedangkan Kecamatan Pangarengan merupakan kecamatan terkecil dengan luas hanya $42,7 \mathrm{~km}^{2}(3,46 \%)$.

Sehubungan dengan itu, Pratiwi menyatakan bahwa pertumbuhan ekonomi yang tinggi tidak serta merta berpengaruh pada kesejahteraan penduduk jika ditinjau dari variabel kemiskinan. Aspek lingkungan menunjukkan kondisi Indeks Kualitas Lingkungan Hidup Jawa Timur masih berada di bawah rata-rata nasional. Kondisi tersebut mengindikasikan perlu adanya perbaikan kualitas lingkungan di Jawa Timur (Pratiwi, N. Dkk, 2018)

Berdasarkan latar belakang tersebut, maka tujuan dari paper ini adalah untuk melakukan kajian isu strategis (tata kelola) pembangunan berkelanjutan di Kabupaten Sampang, Provinsi Jawa Timur. Isu strategis yang dimaksud dibatasi hanya pada isu yang dinilai mendesak untuk diperhatikan dan ditindaklanjuti. Hasil dari kajian ini akan bermanfaat untuk merumuskan beberapa rekomendasi terkait.

\section{Teori}

\subsection{Pengelolaan Pembangunan}

Pengelolaan/ manajemen untuk pembangunan dapat menyiratkan gaya manajemen di mana setiap programkegiatan dilakukan sedemikian rupa untuk meningkatkan (proses dan hasil) pembangunan. Nantinya pembangunan ditingkat masyarakat dapat dianggap sebagai hasil dari kombinasi atau akumulasi perubahan atau pembangunan ditingkat yang lebih rendah. Gagasan manajemen pembangunan sebagai manajemen yang berorientasi pada pembangunan secara konsisten di semua tingkatan.

Implikasi bahwa manajemen pembangunan berarti mengelola, sejauh mungkin, sedemikian rupa untuk meningkatkan potensi orang-orang yang bekerja sama secara langsung. Manajemen untuk pembangunan berhubungan dengan mengelola orang untuk mengeluarkan potensi mereka, untuk pengembangan organisasi yang bertujuan untuk regenerasi nilai-nilai positif dan pandangan masyarakat dimana nilai-nilai pembangunan, seperti memaksimalkan potensi semua individu dan kelompok ditegakkan dalam hak mereka sendiri. Karenanya, pengembangan kapasitas (capacity building) dan pembelajaran organisasi adalah konsep yang sangat penting dalam pembangunan. Manajemen pengembangan, kemudian, bukan hanya masalah menyelesaikan tugas dengan cara terbaik yang tersedia. Hal ini juga berarti secara simultan membangun kapasitas untuk melakukan tugas dimasa depan, dan belajar bagaimana untuk dapat mengatasi isu yang dihadapi saat ini (Thomas, 2000).

\subsection{Pengertian Pembangunan Berkelanjutan}

Secara harfiah, istilah 'keberlanjutan' berarti "kapasitas untuk mempertahankan beberapa entitas, hasil, atau proses dari waktu ke waktu" (Jenkins, 2009: 380) dan melakukan kegiatan yang tidak menghabiskan sumber daya yang menjadi dasar kapasitasnya. Dikarenakan hal ini adalah pemahaman umum tentang keberlanjutan, maka makna ini dapat diposisikan secara analog dengan semua aktivitas manusia dan proses bisnis.

Peraturan Menteri Dalam Negeri Nomor 7 Tahun 2018 tentang Pembuatan dan Pelaksanaan Kajian Lingkungan Hidup Strategis dalam Penyusunan Rencana Pembangunan Jangka Menengah Daerah pada Bab I tentang Ketentuan Umum Pasal satu ayat ke enam mendefinisikan bahwa Pembangunan berkelanjutan adalah upaya sadar dan terencana yang memadukan dimensi lingkungan hidup, sosial, dan ekonomi kedalam strategi pembangunan untuk menjamin keutuhan lingkungan hidup serta keselamatan, kemampuan, kesejahteraan, dan mutu hidup generasi masa kini dan generasi masa depan.

Prinsip utama pembangunan berkelanjutan yang mendasari semuanya adalah integrasi kepedulian lingkungan, sosial, dan ekonomi ke dalam pengambilan keputusan. Framework pembangunan berkelanjutan telah mengintegrasikan pengambilan keputusan pada intinya (Stoddart, 2011). Konsep integrasi inilah yang membedakan keberlanjutan dari bentuk kebijakan lainnya. Dalam praktiknya, pembangunan berkelanjutan membutuhkan integrasi tujuan ekonomi, lingkungan, dan sosial lintas sektor, wilayah, dan generasi. Karenanya, pembangunan berkelanjutan membutuhkan penghapusan 
fragmentasi, yaitu masalah lingkungan, sosial, dan ekonomi harus diintegrasikan di seluruh proses pengambilan keputusan untuk bergerak menuju pembangunan yang benar-benar berkelanjutan. Sebagai misal, pembangunan berkelanjutan hendaknya memberikan solusi dalam hal memenuhi kebutuhan dasar manusia, mengintegrasikan perlindungan lingkungan, mencapai kesetaraan, memastikan penentuan nasib sendiri dan keanekaragaman budaya, serta menjaga integritas ekologis.

\subsection{Pendekatan dan Isu Pembangunan Berkelanjutan}

Pendekatan triple bottom line tersebut, yang mengarahkan atensinya terhadap isu-isu lingkungan, sosial, dan ekonomi, tidak dengan sendirinya berarti bahwa itu adalah tentang keberlanjutan. Karenanya, hal ini perlu dijabarkan secara eksplisit dalam setiap programnya. Suatu program keberlanjutan hendaknya mencakup aksi untuk mencegah ancaman dan dampak yang timbul, tindakan untuk melestarikan dan melindungi lingkungan dari ancaman dan kerusakan, dan pemulihan untuk memperbaikinya. Kontinuitas program tersebut adalah suatu keniscayaan (Ulum \&Ngindana, 124:2017).

Untuk mengklarifikasi relasi antara environment, society, dan economy, maka berikut ini adalah visualisasi Triple Bottom Line dari pembangunan berkelanjutan:
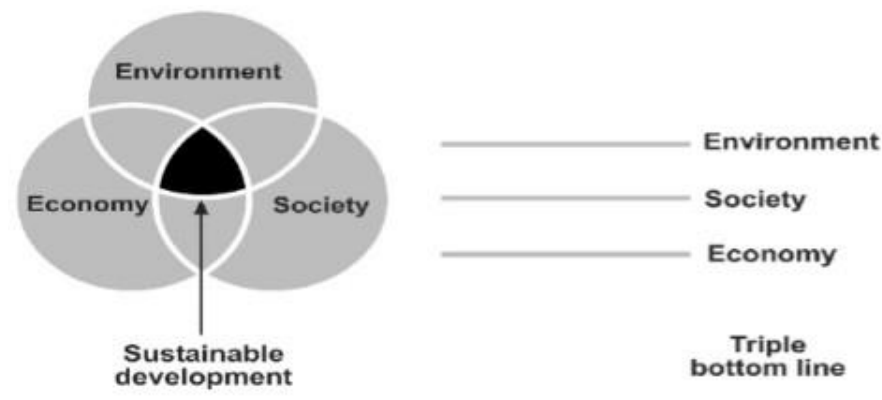

Gambar 1 Triple Bottom Line Pembangunan Berkelanjutan

Sumber: Allan et al., 2008

Berdasarkan gambar diatas, maka dapat diuraikan bahwa Triple Bottom Line (atau disebut sebagai TBL) adalah kerangka kerja (akuntabilitas) melalui interaksi antara aspek sosial, lingkungan (atau ekologois), dan keuangan. Sebagian organisasi telah mengadopsi kerangka kerja TBL untuk mengevaluasi kinerja mereka dalam perspektif yang lebih luas untuk menciptakan nilai-manfaat yang lebih besar.

Selanjutnya, berkaitan dengan isu strategis (strategic issue); diantara para peneliti dalam konteks manajemen strategis, Dutton et al., (1993) telah memberikan perhatian khusus pada gagasan tersebut masalah strategis. Dalam pandangan mereka, tidak ada masalah yang inheren strategis kecuali ketika manajer percaya bahwa masalah itu terkait dengan kinerja organisasi. Hal ini berarti bagaimana strategi yang dilakukan oleh pemerintah dalam mewujudkan pembangunan berkelanjutan.

\section{Metode Penelitian}

Jenis penelitian ini adalah deskriptif dengan pendekatan kualitatif. Teknik pengumpulan data dilakukan melalui Focused Group Discussion (FGD) dan wawancara dengan pimpinan dilingkungan Badan Perencanaan Pembangunan, Penelitian dan Pengembangan Daerah (Bappelitbangda) Kabupaten Sampang. Disamping itu juga dilakukan melalui data sekunder yang diperoleh dari Organisasi Perangkat Daerah, khususnya Badan Perencanaan, Penelitian, dan Pembangunan Daerah (Bappelitbangda) dan Dinas Lingkungan Hidup (DLH) Kabupaten Sampang.

\section{Hasil Penelitian dan Pembahasan}

Perkembangan dan pembangunan suatu daerah membawa dampak positif dan dampak yang negatif bagi kehidupan masyarakat setempat. Hal ini yang mengubah pola pembangunan dari agraris ke industri maka akan berdampak pada perubahan perekonomian, lingkungan dan daya dukung daerah tersebut. Oleh sebab itu, diperlukan suatu strategi yang terencana dalam mengantisipasi kemungkinan munculnya dampak buruk yang akan ditimbulkan dari proses perkembangan dan pembangunan ini.

Selama ini pembangunan di Kabupaten Sampang sebagian mulai berjalan sesuai dengan orientasi untuk pencapaian TPB namun dinilai masih belum optimal sehingga harus menjalankan berbagai upaya ekstra melalui kebijakan, rencana, dan program yang ada. Secara spesifik, hal ini dapat ditinjau pada profil pencapaian TPB di Kabupaten Sampang, khususnya pada indikator yang sudah dijalankan dan (masih) belum mencapai target nasional. Kabupaten ini masih mencapai 52 indikator (25\%) dari total 206 indikator daerah.

Kabupaten Sampang telah melaksanakan Indikator TPB meliputi 16 tujuan. Adapun tujuan yang tidak bisa dilaksanakan adalah tujuan 14 (Ekosistem Kelautan). Tujuan 14 tersebut tidak bisa dilaksanakan karena urusan kelautan dan maritim dipegang perannya oleh Pemerintah Pusat. Untuk lebih jelasnya sebaran indikator TPB di Kabupaten Sampang dalam setiap Tujuan TPB dapat dilihat pada tabel dan gambar sebagai berikut:

Tabel 1 Jumlah Indikator TPB yang Sudah Dilaksanakan dalam TPB

\begin{tabular}{|c|l|c|c|}
\hline No & Nama TPB & $\begin{array}{c}\text { Indikator yang } \\
\text { Sudah } \\
\text { Dijalankan dan } \\
\text { Sudah } \\
\text { Mencapai } \\
\text { Target Nasional }\end{array}$ & $\begin{array}{c}\text { Indikator yang } \\
\text { Sudah } \\
\text { Dijalankan dan } \\
\text { Belum } \\
\text { Mencapai } \\
\text { Target Nasional }\end{array}$ \\
\hline 1 & Tanpa Kemiskinan & 7 & 9 \\
\hline 2 & Tanpa Kelaparan & 5 & 3 \\
\hline 3 & $\begin{array}{l}\text { Kehidupan Sehat dan } \\
\text { Sejahtera }\end{array}$ & 9 & 3 \\
\hline
\end{tabular}




\begin{tabular}{|c|c|c|c|}
\hline No & Nama TPB & $\begin{array}{c}\text { Indikator yang } \\
\text { Sudah } \\
\text { Dijalankan dan } \\
\text { Sudah } \\
\text { Mencapai } \\
\text { Target Nasional } \\
\end{array}$ & $\begin{array}{c}\text { Indikator yang } \\
\text { Sudah } \\
\text { Dijalankan dan } \\
\text { Belum } \\
\text { Mencapai } \\
\text { Target Nasional } \\
\end{array}$ \\
\hline 4 & Pendidikan Berkualitas & 1 & 10 \\
\hline 5 & Kesetaraan Gender & 2 & 5 \\
\hline 6 & $\begin{array}{l}\text { Air Bersih dan Sanitasi } \\
\text { Layak }\end{array}$ & 4 & 2 \\
\hline 7 & $\begin{array}{l}\text { Energi Bersih dan } \\
\text { Terjangkau }\end{array}$ & 0 & 0 \\
\hline 8 & $\begin{array}{l}\text { Pekerjaan layak dan } \\
\text { Pertumbuhan Ekonomi }\end{array}$ & 7 & 6 \\
\hline 9 & $\begin{array}{l}\text { Industri, Inovasi dan } \\
\text { Infrastruktur }\end{array}$ & 0 & 3 \\
\hline 10 & $\begin{array}{l}\text { Berkurangnya } \\
\text { Kesenjangan }\end{array}$ & 2 & 3 \\
\hline 11 & $\begin{array}{l}\text { Kota dan Pemukiman yang } \\
\text { berkelanjutan }\end{array}$ & 3 & 2 \\
\hline 12 & $\begin{array}{l}\text { Konsumsi dan Produksi } \\
\text { yang Bertanggung Jawab }\end{array}$ & 0 & 2 \\
\hline 13 & $\begin{array}{l}\text { Penanganan Perubahan } \\
\text { Iklim }\end{array}$ & 2 & 0 \\
\hline 14 & Ekosistem Lautan & 0 & 0 \\
\hline 15 & Ekosistem daratan & 1 & 1 \\
\hline 16 & $\begin{array}{l}\text { Perdamaian Keadilan } \\
\text { Kelembagaan }\end{array}$ & 4 & 4 \\
\hline 17 & $\begin{array}{l}\text { Kemitraan Untuk } \\
\text { Mencapai Tujuan } \\
\end{array}$ & 2 & 0 \\
\hline \multicolumn{2}{|r|}{ TOTAL } & 49 & 52 \\
\hline
\end{tabular}

Sumber: Hasil analisis, 2019

Berdasarkan data dan grafik diatas dapat dilihat bahwa Kabupaten Sampang telah melaksanakan 101 indikator dari 206 Indikator (49\%) atas pencapaian dari indikator nasional. TPB, TPB 7 dan TBP 14 tidak memiliki indikator yang sudah dijalankan dan sudah mencapai target nasional. Adapun tujuan TPB 14 (Ekosistem Kelautan) merupakan indikator di tingkat nasional yang bukan merupakan kewenangan daerah melainkan kewenangan pusat. Tujuan TPB 7 (Energi Bersih \& Terjangkau) merupakan indikator dimana indikator tersebut bukan merupakan kewenangan daerah.

Selanjutnya, Kabupaten Sampang sebagai salah satu daerah agraris tercatat mempunyai luas sawah mencakup $29 \%$ dari total wilayahnya. Sebagai daerah agraris, upaya optimalisasi sumber air untuk irigasi dan kualitas sumber daya air merupakan sebuah keniscayaan yang harus ditempuh oleh daerah yang bersangkutan. Hal ini dikarenakan sumber air dan irigasi merupakan hal yang sangat vital dalam menjalankan sektor agraris, sebab tanpa adanya ketersediaan sumber air yang cukup untuk mengairi sawah dan lahan pertanian lainnya, maka hasil yang diharapkan tidak akan tercapai. Untuk itu, perlu adanya perencanaan, penataan, dan pengelolaan sumber daya air secara tepat dan rapi. Dengan demikian, sumber pangan yang dihasilkan dari sektor agraris ini akan semakin meningkat yang tentunya juga berdampak pada peningkatan kesejahteraan masyarakat setempat.

Berdasarkan hasil analisis pencapaian target tujuan pembangunan berkelanjutan (TPB), maka diketahui beberapa isu strategis yang menjadi permasalahan, diantaranya adalah belum diketahuinya nilai daya dukung air bersih dan daya dukung pangan, permasalahan limbah, sanitasi, dan kualitas. Diperlukan beberapa exit strategy/ skenario yang tepat untuk mengatasi permasalahan tersebut. Skenario dapat dikatakan juga sebagai exit strategy untuk mengatasi permasalahan yang ada.

Dalam konteks ini, permasalahan yang muncul menuju pencapaian TPB di Kabupaten Sampang meliputi: pangan, limbah dan sampah, serta ketersediaan lahan dan keseimbangan lingkungan. Untuk itu, alternatif skenario dan rekomendasi terkait, yaitu sebagai berikut:

a) Pangan

Perlu adanya diversifikasi (produk) pangan untuk mendukung upaya ketahanan pangan.

b) Limbah dan sampah

Perlu pengembangan sistem manajemen limbah dan sampah terpadu yang berorientasi pada pemanfaatan dan/ atau konservasi lingkungan.

c) Ketersediaan lahan dan keseimbangan kualitasnya

Perlu agar keberadaan Ruang Terbuka Hijau juga mengikutsertakan peran pihak lain untuk berpartisipasi dalam peningkatan kualitasnya.

Adapun isu strategis prioritas dirumuskan dengan melihat pada isu strategis dan permasalahan yang ada di Kabupaten Sampang. Isu strategis prioritas menggambar-kan tingkat prioritas dari isu-isu strategis yang telah dirumuskan dan menjadi bagian yang harus diperhatikan oleh Pemerintah Kabupaten Sampang dalam menyelesaikan permasalahan yang muncul terkait dengan Tujuan pembangunan Berkelanjutan (TPB).

Penilaian permasalahan untuk mendapatkan isu strategis prioritas dilakukan dengan melibatkan OPD di Kabupaten Sampang, khususnya terkait dengan penilaian terhadap limaaspek, yaitu: Berhubungan dengan Visi dan Misi, Prioritas Daya Dukung dan Daya Tampung (DDDT), Tingkat Kepentingan untuk Diselesaikan, termasuk dalam Standar Pelayanan Minimal (SPM), serta merupakan prioritas nasional dan provinsi. Sedangkan peringkat gap secara langsung dapat dirumuskan dengan mendasarkan pada hasil analisis, dimana indikator TPB diperingkatkan berdasarkan besarnya gap capaian Kabupaten Sampang dengan target RPJMN Tahun 2019. Hal-hal yang perlu mendapat perhatian sebagai isu strategis prioritas di Kabupaten Sampang, antara lain terkait dengan lima poin sebagai berikut:

a) Pengentasan kemiskinan;

b) Peningkatan akses dan pemerataan pendidikan;

c) Pengurangan kekerasan pada perempuan dan anak;

d) Pengurangan risiko bencana; dan

e) Pengelolaan limbah dan sampah.

Tentunya hal ini juga tidak terlepas dari kebijakan alokasi anggaran. Artinya, upaya-upaya yang dilakukan untuk menuntaskan atau menyelesaikan isu strategis prioritas berdasarkan pada kemampuan finansial atau 
keuangan daerah (APBD). Maka dari itu, tidak semua isu strategis lalu menjadi prioritas, namun dibatasi pada beberapa hal yang secara bersamaan juga merupakan target-sasaran di tingkat provinsi bahkan nasional.

Atas dasar hal tersebut, perhatian Pemerintah Kabupaten Sampang melalui semua Organisasi Perangkat Daerah (OPD)-nya dapat fokus pada isu yang diprioritaskan. Meskipun demikian, kebijakan/ rencana/ program (KRP) terkait atau yang lain juga tetap diperlukan untuk mendukungnya. Untuk itu, Pemerintah Kabupaten Sampang, berupaya memperhatikan beberapa isu, mulai dari Pengentasan Kemiskinan hingga Pengelolaan Limbah dan Sampah, melalui KRP dalam rangka pencapaian Tujuan Pembangunan Berkelanjutan (TPB).

Skala prioritas ini kemudian menjadi acuan bagi pemerintah daerah untuk menentukan target-target tertentu yang ingin dicapai dalam pembangunan. Dari kelima poin isu strategis prioritas yang telah dirumuskan tersebut, Pemerintah Kabupaten Sampang dapat menentukan sejauh mana target yang ingin dicapai dalam hal pengentasan kemiskinan, peningkatan akses dan pemerataan pendidikan, pengurangan kekerasan pada perempuan dan anak, pengurangan risiko bencana, dan pengelolaan limbah dan sampah. Dengan demikian, segala strategi atau upaya yang dilakukan untuk mencapai tujuan tersebut dapat terukur dan output serta outcome yang dihasilkan pun jelas dan terarah.

\section{Kesimpulan}

Secara umum selama ini pembangunan di Kabupaten Sampang sebagian sudah mulai berjalan sesuai dengan orientasi untuk pencapaian tujuan pembangunan ber-kelanjutan (TPB). Harapannya, pemenuhan tujuan pembangunan berkelanjutan terus diupayakan dan dapat mencapai target yang telah ditentukan. Dikarenakan dinilai masih belum optimal, maka hendaknya men-jalankan berbagai upaya ekstra melalui kebijakan, rencana, dan program.

Untuk itu, diperlukan perhatian dan upaya yang terkait dengan:

a) Penyediaan/ ketersediaan database yang memadai sehingga dapat dijadikan sebagai dasar analisis bagi kebijakan, rencana, dan program Pemerintah Kabupaten Sampang;

b) Optimalisasi koordinasi lintas Organisasi Perangkat Daerah (OPD) dilingkungan Kabupaten Sampang, baik yang menjadi leading sector maupun yang tidak langsung, agar bekerjasama secara lebih intensif demi keberhasilan capaian indikator TPB sehingga nantinya dapat memenuhi target nasional; dan

c) Peningkatan/ perluasan partisipasi publik, khususnya warga masyarakat Kabupaten Sampang, dalam rangka percepatan pencapaian TPB.
Melalui rekomendasi tersebut diharapkan TPB di Kabupaten Sampang dapat terwujud dengan optimal dan membawa dampak, serta kontribusi yang positif bagi perkembangan dan kemajuan lingkungan, perekonomian, serta kehidupan masyarakat setempat.

\section{Daftar Pustaka}

Allan, L., P. Godfrey., \& G.M. Allan. (2008). Port as Sustainable Complex Systems. Journal of Maritime Research, Vol. V, No. 3, pp.55-66.

Dutton, J.E., \& Ashford S. J. (1993). Selling Issues to Top Management. Academy of Management Review, Vol. 18(3), pp.397-428.

Jenkins, W. (2009). Berkshire Encyclopedia of Sustainability: The Spirit of Sustainability, Vol. 1 (1st ed.). Berkshire: Berkshire Publishing Group.

Peraturan Menteri Dalam Negeri Nomor 7 tahun 2018 tentang Pembuatan dan Pelaksanaan Kajian Lingkungan Hidup Strategis dalam Penyusunan Rencana Pembangunan Jangka Menengah Daerah.

Pratiwi, N., Santosa, Dwi Budi., \& Ashar, Khusnul. (2018). Analisis Implementasi Pembangunan Berkelanjutan di Jawa Timur. Jurnal Ilmu Ekonomi dan Pembangunan (JIEP), Vol. 18, No 1, pp.1-13.

Stoddart, H (ed). (2011). A Pocket Guide to Sustainable Development Governance (First Edition: For Comment by 15th July 2011). Stakeholder Forum \& Commonwealth Secretariat, London.

Thomas, A. (2000). What Makes Good Development Management? Tersedia pada https://oxfamilibrary.openrepository.com/bitstrea $\mathrm{m} /$ handle/10546/122767/bk-conflictdevelopment-preface-essays-1-7-010101en.pdf?sequence $=20 \&$ is Allowed $=y$ [Diakses pada 11 Agustsu 2019].

Ulum, M.C., \& Ngindana, R. (2017). Environmental Governance: Isu, Kebijakan, dan Tata Kelola Lingkungan Hidup. Malang: UB Press. 